\title{
Effect of Eight Container Types and Root Pruning During Nursery Production on Root Architecture of Acer rubrum
}

\author{
Edward F. Gilman, Maria Paz, and Chris Harchick
}

\begin{abstract}
There is a general understanding that roots deflect when striking solid nursery container walls, and that on trees with good vitality this occurs within weeks of shifting into larger containers. Root architecture is poorly understood when observed in containers with walls constructed of porous plastic and of materials other than plastic. The objective of this study was to measure impacts of container type, root pruning when shifting to a larger container, and cardinal direction on root architecture in nursery containers up to the \#45 size (approximately $170 \mathrm{~L}$ ). Trunk diameter in \#45 containers varied less than $5 \mathrm{~mm}$ among eight container types and was not impacted by root pruning. More root growth occurred in the northern than southern half of containers. Container type had a small impact on root architecture; in contrast, root pruning by shaving the periphery of the root ball at each shift had a large impact. Shaving when shifting dramatically reduced the percentage of trees graded as culls and suppressed stem-girdling root formation compared to not shaving. Shaving shifted deflected woody root mass from the interior of the root ball to the exterior, making it simple to remove peripheral roots when planting into the landscape.

Key Words. Acer rubrum; Circling Roots; Containers; Descending Roots; Porous-Walled Containers; Red Maple; Root Collar; Shaving; Solid-walled Containers; Straight Roots.
\end{abstract}

Root defects in container-grown nursery stock were rated as the top tree-related challenge at the International Research Symposium of the Landscape Below Ground III Conference, held at The Morton Arboretum in October 2008. Impacts of poor root systems may not be apparent for many years after planting (Gilman et al. 2013). Arborists place responsibility for correcting poor root systems with nursery professionals and landscape contractors because arborists do not grow trees and are typically absent when trees are installed. Growers have begun responding by including root circling (Anonymous 2014) and planting depth (Anonymous 2015) as downgrading factors in nursery stock standards and grading systems.

Trees grown in containers develop root systems that are different from those grown in field soil, and the root systems in both are different from trees in the forest. Instead of spreading to their natural distance and depth (Lyford and Wilson 1964; Halter et al. 1993), roots on shade trees are deflected up, down, or around by container walls (Harris et al. 1971; Harris and Gilman 1991) or can deflect back toward the trunk (Fare 2005). Root architecture in the root ball affects how roots grow out into landscape soil (Marshall and Gilman 1998). Deflected roots growing tangent to, around, and close to the trunk can form bark inclusions between the root and trunk, likely because of poor graft compatibility between trunk and root tissue. This can lead to reduced passage of substances through the constricted vascular tissue at this point on the trunk (Nichols and Alm 1983). Moreover, roots growing tangent to or around and touching the trunk were recently associated with trunk bark death and cracks on Acer rubrum L., but not Ulmus parvifolia Jacq. (Gilman et al. 2015a).

A number of containers have been designed to manage root growth. Previous studies showed that those generally referred to as air root pruning containers reduce root circling (Marshall and Gilman 1998; Stoven O'Conner et al. 2013) and had less packed roots, less spiraling roots, and fewer L-shaped roots (Ortega et al. 2006); however, no container eliminates root defects. For 
example, Gilman and Harchick (2008) reported that nearly all trees produced in one air root pruning container-without mechanical root pruning-produced enough circling roots to grade them as culls according to Florida Grades and Standards for Nursery Plants (Anonymous 2015). The first stage (Gilman et al. 2010a) of the current study showed that certain \#3 (standard size designation, Anonymous 2014) containers induced circling roots; whereas, others induced a more descending root system. A combination of roots growing horizontally and downward into landscape soil may result in the most stable trees (Gilman and Harchick 2014).

Root pruning can also be used to manage root growth in containers. Root pruning of seedlings reduced root defects (Harris et al. 1971) and produced more symmetrically distributed lateral roots years after planting (Krasowski 2003). One study showed that light cutting of circling roots of shrubs enhanced the amount of roots growing into substrate outside of the original root ball (Blanusa et al. 2007). However, nearly all studies were performed on small seedlings, not landscape-sized trees. Preliminary work showed that shaving the periphery and bottom of the root ball when \#3 containers were shifted to \#15 containers was an efficient method of nearly eliminating root defects on seven temperate and tropical tree species (Gilman et al. 2010b).

Less understood is the impact on root architecture from growing in containers with walls constructed of perforated plastic and other porous materials. This project reports on the continuation of a study published (Gilman et al. 2010a) on trees produced in eight types of \# 3 containers. The objective of this study was to measure impacts of container type, root pruning during shifting to a larger container, and cardinal direction (north half versus south half of root ball) on root architecture in identical types of $\# 15$ and \#45 containers. A cultivar of red maple (Acer rubrum L. 'Florida Flame') was chosen for the study because red maple is a common shade tree grown throughout much of North America, and trees in the Acer genus develop root defects readily (Tate 1980). 'Florida Flame' is propagated by rooting current-year shoots removed from parent trees; this procedure removes genetic variability among individuals, compared to a cultivar grafted to seedling root stock.

\section{MATERIAL AND METHODS}

In April 2008, 384 uniform rooted cuttings approximately $15 \mathrm{~cm}$ tall of Acer rubrum L. 'Florida Flame' rooted in circular containers $(5.1 \mathrm{~cm}$ top diameter, $13 \mathrm{~cm}$ tall ribbed containers, 38 Groove Tube, Growing Systems, Inc., Milwaukee, Wisconsin, U.S.) were planted into eight different \#3 (approximately $11 \mathrm{~L}$ ) container types (Table 1). The point where the topmost root emerged from the stem (root collar) was placed $13 \mathrm{~mm}$ below substrate surface by removing an appropriate amount of substrate and associated roots from the top of the liner root ball where needed.

Substrate was 20: 60: 20 (New Florida peat: pine bark: sand, by volume; Florida Potting Soil, Inc., Orlando, Florida, U.S.) for RT, RB, FN, CR, and JP (Table 1), and 50: 40: 10 (New Florida peat: pine bark: sand, by volume) for AP, SP, and SS. New Florida peat is a compost of Florida peat and hardwood fines (Florida Potting Soils, Inc., Davenport, Florida, U.S.). Substrates were recommended by the container manufacturers and are considered an integral part of the growing systems. Substrate volumes in \#3 containers were standardized, except for JP, which was $15 \%$ smaller (Gilman et al. 2010a). Despite conformance with industry standards (Anonymous 2014), dimensions and volumes for \#15 and \#45 containers varied considerably by manufacturer (Table 1), so substrate volumes could not be standardized. Each was filled with substrate to near the top of the side wall when shifting into the container. Fertilizer $\left(18 \mathrm{~N}: 5 \mathrm{P}_{2} \mathrm{O}_{5}: 10 \mathrm{~K}_{2} \mathrm{O}\right.$, controlled release; Harrells, Inc., Lakeland, Florida, U.S.) was incorporated into substrate prior to shifting at $\left(0.011 \mathrm{~g} / \mathrm{cm}^{3}\right)$, and no other fertilizer was applied.

Trees in \#3 containers were placed on woven black ground cloth in Gainesville, Florida, U.S. (USDA Hardiness Zone 8b) spaced pot-to-pot (i.e., touching one another) except for a $0.5 \mathrm{~m}$ wide walk space every four rows. Containers were spaced so tree trunks were $0.4 \mathrm{~m}$ apart in July 2008 to allow growth of branches along the lower trunk. Trees were arranged in a randomized complete block design with one container of each type in each block. Each was irrigated two to three times totaling 3.8 L daily through one Roberts (Roberts Irrigation Products, Inc., San Marcos, Idaho, U.S.) Spot-Spitter per container until autumn 2008 when irrigation frequency and volume were reduced for the dormant season. Trees were staked in May 2008 to hold 
Table 1. Manufacturer, dimensions, and abbreviations for eight types of \#15 and \#45 containers.

\begin{tabular}{|c|c|c|c|c|}
\hline \multirow[t]{2}{*}{ Manufacturer and abbreviation } & \multicolumn{2}{|c|}{$\begin{array}{l}\text { Substrate fill height/container } \\
\text { top diameter at fill height }(\mathrm{cm})\end{array}$} & \multicolumn{2}{|c|}{ Substrate volume $\left(\mathrm{cm}^{3}\right)$} \\
\hline & $\# 15$ & $\# 45^{\circ}$ & $\# 15$ & $\# 45$ \\
\hline $\begin{array}{l}\text { Air-Pot }{ }^{\oplus} \text { - AP } \\
\text { Caledonian Tree Company, Ltd. } \\
\text { Scotland }\end{array}$ & $33 / 46$ & $40 / 76$ & 54,210 & 182,437 \\
\hline $\begin{array}{l}\text { Cool Ring }{ }^{\text {Tx }}-\text { CR } \\
\text { The Cool Ring }{ }^{\text {max }} \text { Company } \\
\text { Lakeland, Florida, U.S. }\end{array}$ & $29 / 44$ & $41 / 76$ & 45,328 & 185,333 \\
\hline $\begin{array}{l}\text { Fanntum }^{\text {nit }} \text { - FN } \\
\text { Fanntum Products, Inc. } \\
\text { Statesville, North Carolina, U.S. }\end{array}$ & $24 / 51$ & $54 / 76$ & 45,331 & 149,097 \\
\hline $\begin{array}{l}\text { JackPot }^{\mathrm{T \omega}} \text { - JP } \\
\text { Legacy Nursery Products, LLC } \\
\text { Palm City, Florida, U.S. }\end{array}$ & $31 / 39$ & $36 / 61$ & 38,651 & 103,787 \\
\hline $\begin{array}{l}\text { RootBuilder }{ }^{\ominus} \text { II - RB } \\
\text { Rootmaker }{ }^{\circ} \text { Products Company, LLC } \\
\text { Huntsville, Alabama, U.S. }\end{array}$ & $38 / 42$ & $38 / 69$ & 52,559 & 140,737 \\
\hline $\begin{array}{l}\text { RootTrapper }^{\circledR} \mathrm{II}-\mathrm{RT}^{\mathrm{z}} \\
\text { Rootmaker } \\
\text { Huntsville, Aladucts Company, UL.S. }\end{array}$ & $31 / 43$ & $30 / 74$ & 44,634 & 127,182 \\
\hline $\begin{array}{l}\text { Smart Pot } \operatorname{Pro}^{\star} \text { - SP } \\
\text { Root Control, Inc. } \\
\text { Oklahoma City, Oklahoma, U.S. }\end{array}$ & $31 / 44$ & $46 / 62$ & 47,299 & 139,058 \\
\hline $\begin{array}{l}\text { Smooth-sided, solid-walled - SS } \\
\text { Nursery Supplies, Inc. } \\
\text { Chambersburg, Pennsylvania, U.S. }\end{array}$ & $35 / 44$ & $47 / 61$ & 44,710 & 167,703 \\
\hline
\end{tabular}

them erect and to develop a straight trunk. Branches on trees were pruned twice during the growing season to develop a dominant trunk and leader by reducing competing branch length with heading cuts. Trunk diameter $15 \mathrm{~cm}$ above substrate and height from substrate to top of tree were measured September 2008 and each subsequent autumn.

Root balls on nine trees of each \#3 container type (72 trees) were washed of substrate in November 2008, and the root balls were evaluated (see Gilman et al. 2010a for details). In February 2009, 288 total trees in \#3 containers were shifted to the same eight types of \#15 containers with the same substrate described above and placed $0.4 \mathrm{~m}$ apart on woven black ground cloth in a randomized complete block design. Blocks were kept intact when shifting to the larger size. Trunks were marked on the north side to maintain trees in precisely the same cardinal direction throughout the study. The RM was replaced by RT (a recommended type of fabric container by the same manufacturer) because RM sizes larger than \#5 were not available; this treatment will be referred as
RT. Root balls on half of the trees of each \#3 container type were pruned during the shifting process in one of two ways: 1) no root pruning, or 2) shaving off the outer $3 \mathrm{~cm}$ of the root ball sides and bottom. Shaving was performed using a sharp straight-backed digging shovel, while the root ball was standing upright on the ground out of the container; the bottom was removed in the same manner while the tree was lying on the ground. Removed roots were as large as $8 \mathrm{~mm}$ diameter. Branches on trees in \#15 containers were pruned twice using heading and reduction cuts to maintain a dominant leader (Gilman and Lilly 2008). The remaining 24 trees from \#3 containers $(8$ container types $\times 3$ replicates $=24)$ were planted directly into the ground (see Gilman et al. 2015b).

In November 2009, root balls from \#15 containers (8 container types $\times 2$ root prunings $\times 5$ replicates $=80$ trees) were washed of substrate before roots were measured in a variety of ways. Root measurements on \#15 root balls included the following: percent trees grading as a cull, according to Florida Grades and Standards for Nursery Plants (cull = 
roots larger than one-tenth the trunk diameter in the top half of the root ball, circling more than one-third around trunk, Anonymous 2015); percent trunk circled at \#3 and \#15 positions; percent trees with roots $>5 \mathrm{~mm}$ diameter growing over root collar at the trunk; diameter of five largest roots on north and south half of \#15 root ball periphery; number of radial roots (roots $>2 \mathrm{~mm}$ diameter growing straight (with less than a 45 degree turn) from trunk reaching \#15 container wall) measured between \#3 and \#15 container wall positions; and diameter of the five largest roots at position of \#3 container before descending, circling, kinking, ascending, or growing straight into \#15 substrate.

In February 2010, 160 trees ( 8 container types $\times 2$ root prunings $\times 10$ replicates $)$ were shifted into the identical type \#45 containers with the same substrate described above on $1.8 \mathrm{~m}$ spacing in a randomized complete block design. Blocks were kept intact when shifting to the larger size. Root balls on half of the trees of each container type (the same trees shaved when shifting into \#15) were shaved, as previously described, and half were not, as they were shifted into \#45 containers. The north mark on all trunks was placed due north. Branches on trees were pruned twice using reduction and heading cuts to maintain a dominant leader. The remaining 48 trees from \#15 containers (8 container types $\times 2$ root pruning $\times 3$ replicates) were planted directly into the ground (see Gilman et al. 2015b).

In May 2011,80 rootballs from the \# 45 containers ( 8 container types $\times 2$ root prunings $\times 5$ replicates $=80$ trees) were washed of substrate before roots were measured in a variety of ways. Some attributes were measured between the position of the \#15 and \#45 containers; many measured attributes resulted from root defections that occurred when trees were in the smaller \#3 and \#15 containers. Root measurements on \#45 root balls included the following: percent trees grading as a cull, according to Florida Grades and Standards for Nursery Plants (Anonymous 2015); percent trunk circled at \#3, \#15, and \#45 positions as indicated by root deflections at the former position of these containers; percent trunk circumference circled by roots at the \#3 and \#15 positions; percent trees with roots $>5 \mathrm{~mm}$ diameter growing over root collar at the trunk; diameter of the five larg- est roots on the north and south half (referred to as cardinal direction) of \#45 root ball periphery; number of radial roots (roots $>2 \mathrm{~mm}$ diameter growing straight (with less than a 45 degree turn) from trunk reaching \#45 container wall) measured between \#15 and \#45 container wall positions; and diameter of the five largest roots at position of \#3 container before descending, circling, kinking, ascending, or growing straight into \#15 substrate. The remaining 80 trees (8 container types $\times 2$ root pruning $\times 5$ replicates) were planted into the ground with the north mark facing due north (see Gilman et al. 2015b).

\section{Statistical Analysis}

Data were analyzed at each harvest date with twoway analysis of variance (ANOVA), with container type and root pruning serving as main effects in a randomized complete block design using the GLM procedure in SAS (1992). Percentages were analyzed in the Genmod procedure within SAS. Two attributes were measured in the northern half of the root ball and compared to those in the southern half; this main effect was referred to as cardinal direction. These attributes included number of roots $>2 \mathrm{~mm}$ diameter growing straight (with less than a 45 degree turn) from trunk reaching \#15 container wall, measured between \#3 and \#15 container wall positions, and diameter of the five largest roots on the root ball periphery. Three-way ANOVA was used to analyze these data with container type, root pruning, and cardinal direction serving as main effects in a randomized complete block design. Duncan's multiple range test was used to separate main effect means at $P<0.05$; LSD was used to separate interaction means at $P<0.05$ unless indicated.

\section{RESULTS}

\section{Shoot Growth}

Trunk diameter differences for finished trees varied less than $5 \mathrm{~mm}$ among container types in \#3, \#15, and \#45 containers (Table 2). Trees in \#45 AP, SP, and SS had larger trunk diameters than those in JP and $\mathrm{RB}$ at the end of the study; however, differences were small $(<5 \mathrm{~mm})$. Tree height differences were less than $15 \%, 8 \%$, and $4 \%$ for trees in the $\# 3, \# 15$, and \#45 container types, respectively. There was no 
est roots at the \#3 position, reduced the percentage of circling and ascending roots at the position of the \#3 container (Table 4$)$, and reduced $(P<$ $0.0001)$ the percentage of trunk circumference circled with roots at the \#3 position from $57 \%$ to $16 \%$ as averaged across container types (Figure 1). Root-ball shaving decreased (by nearly half) the diameter of the five largest roots at the position of the $\# 3$, while increasing (by $25 \%$ or more) the diameter of the five largest roots at the periphery of the \#15 on the north and south sides of the root ball (Table 4). Number of roots growing straight from the trunk between the \#3 and \#15 containers and diameter of roots at the periphery of the \#15 container were larger on the north than south side of the root ball (Table 5).

Root pruning when shifting \#3 trees into \#15 containers interacted with container type for two measured root attributes: percent of trunk circled with roots at the \#3 position, and number of radial roots between the \#3 and \#15 container positions. Radial roots were those $>2 \mathrm{~mm}$ diameter growing straight away from the trunk between the \#3 and \#15 container positions. Among trees not pruned when shifted, those in JP had the smallest percentage of trunk circled at the \#3 position (Figure 1). Root balls of finished trees in \#15 SS and RT not shaved had a similar percentage of trunk circled by roots at the position of the \#3 container; and trees in both had a larger percentage of the trunk circled with roots than in all others. Root pruning reduced the percentage of trunk circled with roots for all container types, but the amount varied (Figure 1). For example, pruning \#3 RB reduced circling roots by a little less than $50 \%$, compared to not pruning; whereas, pruning AP or JP nearly eliminated circling roots.

Trees in JP and SP had the most radial roots among trees not root pruned when shifted (Figure 2); trees not root pruned in SS had the fewest radial roots. For all container types, except JP, root-ball shaving increased the number of radial roots, but the amount depended on the container type. For example, shaving nearly doubled radial root number in FN and SS, whereas increases were smaller for other containers, such as CR and SP. As further evidence of interaction between root-ball shaving and container type, trees in non-shaved JP and SP had as many radial roots as those in shaved CR, RB, RT, and SS (Figure 2).

Table 4. Effects of root pruning \#3 root balls when shifting 'Florida Flame' red maple into \#15 containers on attributes of harvested trees in \#15 containers.

\begin{tabular}{|c|c|c|c|c|c|c|c|}
\hline \multirow[t]{2}{*}{$\begin{array}{l}\text { Root } \\
\text { pruning }^{2}\end{array}$} & \multirow[t]{2}{*}{$\begin{array}{l}\% \text { trees graded as } \\
\text { cull at } \# 3 \text { container } \\
\text { position }\end{array}$} & \multirow{2}{*}{$\begin{array}{l}\% \text { trees with roots }>5 \\
\text { mm diameter over root } \\
\text { collar within } \# 3 \\
\text { container dimensions }\end{array}$} & \multirow[t]{2}{*}{$\begin{array}{l}\text { Diameter five largest } \\
\text { roots at \#3 container } \\
\text { position }(\mathrm{mm})^{\mathrm{x}}\end{array}$} & \multirow{2}{*}{$\begin{array}{l}\text { Diameter of five largest } \\
\text { roots on northern } \\
\text { periphery of \#15 root ball } \\
(\mathrm{mm})^{\mathrm{w}}\end{array}$} & \multirow{2}{*}{$\begin{array}{l}\text { Diameter of five largest } \\
\text { roots on southern } \\
\text { periphery of \#15 root ball } \\
(\mathrm{mm})^{\mathrm{w}}\end{array}$} & \multicolumn{2}{|c|}{$\begin{array}{l}\% \text { of five largest roots at } \# 3 \\
\text { container position in the top } \\
\text { half of root ball that either }\end{array}$} \\
\hline & & & & & & Circled & Ascended \\
\hline None & $78 \mathrm{a}^{\mathrm{u}}$ & $48 \mathrm{a}$ & $12.7 \mathrm{a}$ & $4.5 \mathrm{~b}$ & $4.2 \mathrm{~b}$ & $40 \mathrm{a}$ & $6 \mathrm{a}$ \\
\hline Shaved & $23 \mathrm{~b}$ & $27 \mathrm{~b}$ & $6.9 \mathrm{~b}$ & $6.0 \mathrm{a}$ & $5.2 \mathrm{a}$ & $18 \mathrm{~b}$ & $1 \mathrm{~b}$ \\
\hline
\end{tabular}

Table 5. Root attributes in the north and south half of harvested \#15 and \#45 red maple root balls.

\begin{tabular}{|c|c|c|c|c|}
\hline Cardinal direction & $\begin{array}{l}\text { No. of radial roots } \\
\text { in } \# 15^{z}\end{array}$ & $\begin{array}{l}\text { No. of radial roots } \\
\text { in } \# 45^{y}\end{array}$ & $\begin{array}{l}\text { Diameter of five largest } \\
\text { roots on } \# 15 \text { root ball } \\
\text { periphery }(\mathrm{mm})^{x}\end{array}$ & $\begin{array}{l}\text { Diameter of five largest } \\
\text { roots on } \# 45 \text { root ball } \\
\text { periphery }(\mathrm{mm})^{x}\end{array}$ \\
\hline North 180 degrees & $30 a^{w}$ & $64 a^{x}$ & $5.8 \mathrm{a}$ & $6.7 \mathrm{a}$ \\
\hline South 180 degrees & $27 \mathrm{~b}$ & $51 \mathrm{~b}$ & $4.8 \mathrm{~b}$ & $5.7 \mathrm{~b}$ \\
\hline
\end{tabular}

${ }^{z}$ Number of roots $>2 \mathrm{~mm}$ diameter growing straight (with less than a 45 degree turn) from trunk between \#3 and \#15 container position. Trees in \#3, \#15, and \#45 containers for 7,9 , and 15 months, respectively.

y Number of roots $>2 \mathrm{~mm}$ diameter growing straight (with less than a 45 degree turn) from trunk between \#15 and \#45 container position.

${ }^{x}$ Roots in the outer $3 \mathrm{~cm}$ in the north or south half of root ball; no other root attributes were significant.

${ }^{w}$ Means in a column with a different letter are statistically different at $P<0.01 ; \mathrm{n}=80$, averaged across container type and root pruning due to insignificant interactions $(P>0.10)$. 


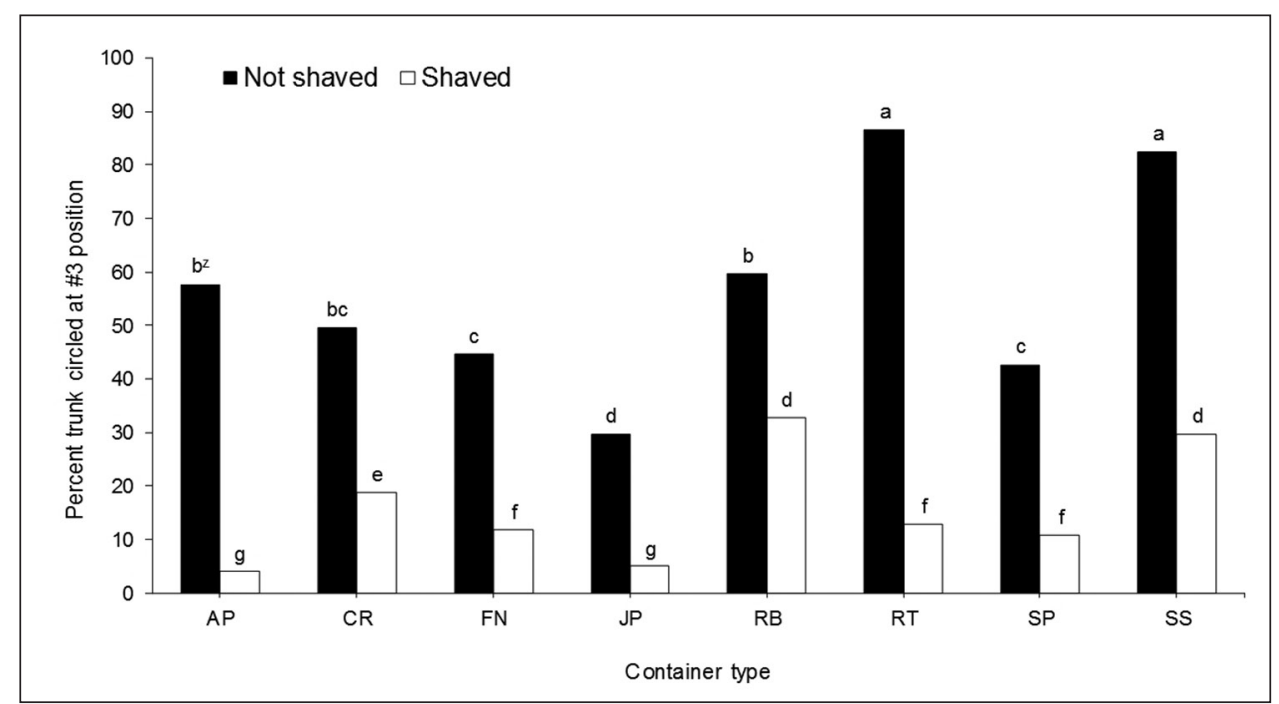

Figure 1. Percent trunk circumference circled with roots $>3 \mathrm{~mm}$ diameter (harvested from \#15 containers) at the \#3 container position following shaving or not when shifting eight types of \#3 containers (shaving removed the outer $3 \mathrm{~cm}$ of the root ball periphery and bottom) into \#15 containers. ${ }^{2}$ Bars with a different letter are statistically different at $P<0.05 ; n=5$. See Table 1 for descriptions of container types.

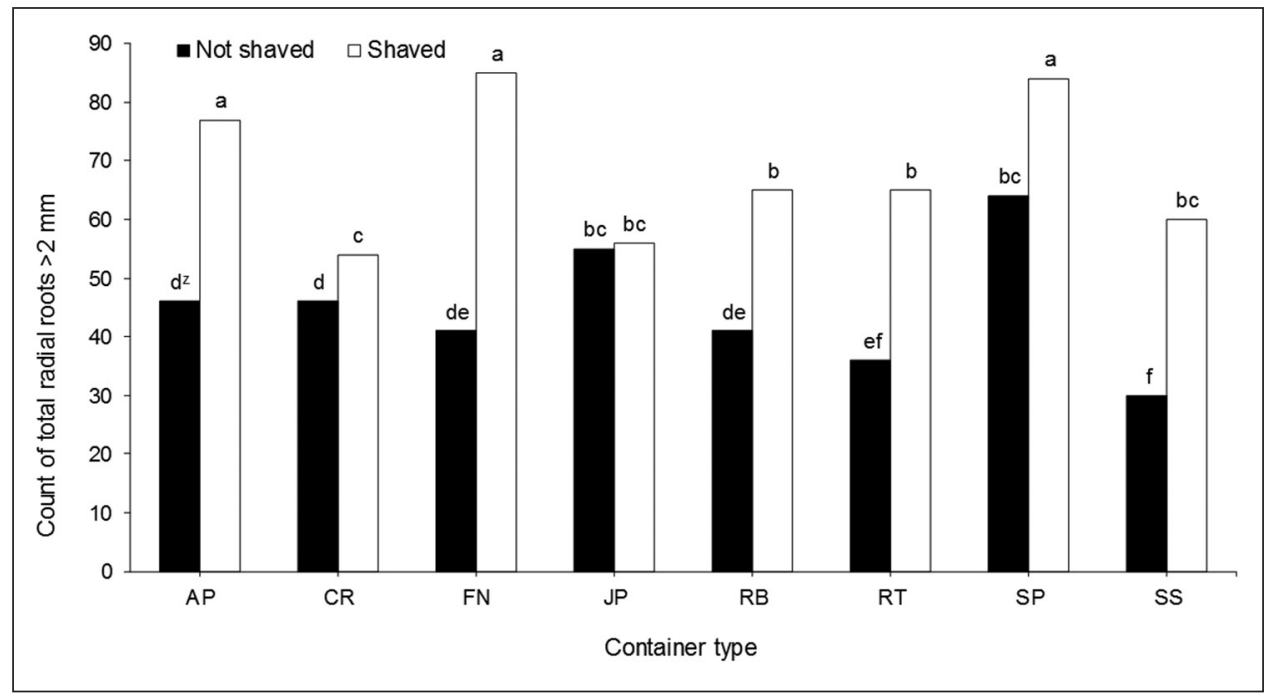

Figure 2. Number of radial roots (roots $>2 \mathrm{~mm}$ diameter growing straight, with less than a 45 degree turn, from trunk reaching \#15 container wall) measured between \#3 and \#15 container wall positions on trees where root balls were shaved or not when shifted into eight \#15 container types (shaving removed the outer $3 \mathrm{~cm}$ of the root ball periphery and bottom). ${ }^{\text {Bars }}$ with a different letter are statistically different at $P<0.05 ; n=5$. See Table 1 for descriptions of container types.

\section{Characteristics of Root Balls Har- vested from \#45 Containers}

The main effect of container type was significant for three attributes without interacting with root pruning (Table 6). Trees in FN had larger diameter roots on the northern half circumference of the \#45 periphery than all other container types, except CR and RT; roots in the southern half in FN and SP were larger than those in AP and SS. Roots at the position of \#3 in RB and SS containers had smaller diameter roots than those in CR, FN, JP, and SP. The most common fate of the five largest roots measured at the position of the \#15 container wall was to circle (56\%), and there 
were no differences among container types (data not shown); descending was significantly $(P=$ $0.05)$ less common $(32 \%)$ and also did not vary among types. Only $12 \%$ of the five largest roots ascended the container wall or kinked to grow back toward the trunk, and there were no differences among container types (data not shown).

Shaving the root ball periphery when shifting from either the \#3 or \#15 containers dramatically reduced the percentage of trees graded as culls at either position (\#3 and \#15) in the root ball (Table 7 ). Shaving reduced the percentage of trees with roots $>5 \mathrm{~mm}$ diameter over the root collar within \#3 container dimension, and reduced diameter of the largest roots at \#15 container position. In contrast, shaving increased the diameter of roots on the periphery of finished trees in \#45 containers. The number of roots growing straight from the trunk (radial roots) between the \#15 and \#45 containers and diameter of roots at the periphery of the \#45 container were larger on the north, rather than south side of the root ball (Table 5).

The number of roots growing straight from the trunk between the \#15 and \#45 containers (radial roots) was approximately double for the shaved than the not shaved treatment for all containers, except RT (Figure 3). Container type had no impact on number of radial roots when root balls were shifted to a larger container without shaving. However, SP had more radial roots than $\mathrm{CR}, \mathrm{FN}, \mathrm{RB}$, and $\mathrm{RT}$ when root balls were shaved. Percentage of trunk circled with roots larger than $3 \mathrm{~mm}$ diameter depended on container type and root pruning (Table 8), although in all cases shaving substantially $(P<0.001)$ reduced root circling at the \#3 and \#15 positions (Figure 4). In contrast, circling at the \#45 position on shaved trees was greater than or equal to circling without shaving for all container types, except RT and SS, which had a smaller percentage of the trunk circled as a result of shaving.

Table 6. Root ball attributes of 'Florida Flame' red maple harvested from eight different \#45 container types.

\begin{tabular}{|c|c|c|c|}
\hline Container type & $\begin{array}{l}\text { Diameter of five largest } \\
\text { roots on north periphery } \\
\text { of } \# 45 \text { root ball }(\mathrm{mm})^{z}\end{array}$ & $\begin{array}{l}\text { Diameter of five largest } \\
\text { roots on south periphery } \\
\text { of } \# 45 \text { root ball }(\mathrm{mm})^{z}\end{array}$ & $\begin{array}{l}\text { Diameter of five largest } \\
\text { roots at position of \#3 } \\
\text { root ball }(\mathrm{mm})^{y}\end{array}$ \\
\hline $\mathrm{AP}^{\mathrm{x}}$ & $6.0 c^{w}$ & $4.7 \mathrm{~b}$ & $6.7 \mathrm{bc}$ \\
\hline CR & $7.8 \mathrm{ab}$ & $5.8 \mathrm{ab}$ & $11.0 \mathrm{a}$ \\
\hline FN & $8.2 \mathrm{a}$ & $7.0 \mathrm{a}$ & $10.7 \mathrm{a}$ \\
\hline JP & $5.7 \mathrm{c}$ & $5.4 \mathrm{ab}$ & $9.5 \mathrm{ab}$ \\
\hline $\mathrm{RB}$ & $6.3 \mathrm{bc}$ & $5.6 \mathrm{ab}$ & $5.7 \mathrm{c}$ \\
\hline RT & $6.9 \mathrm{abc}$ & $5.7 \mathrm{ab}$ & $7.2 \mathrm{bc}$ \\
\hline SP & $6.4 \mathrm{bc}$ & $7.0 \mathrm{a}$ & $10.8 \mathrm{a}$ \\
\hline SS & $6.4 \mathrm{bc}$ & $4.5 \mathrm{~b}$ & $6.3 c$ \\
\hline
\end{tabular}

${ }^{\mathrm{z}}$ Roots in the outer $3 \mathrm{~cm}$ in the north or south 180 degree circumference of root ball. Trees in \#3, \#15, and \#45 containers for 7 , 9 , and 15 months, respectively.

${ }^{y}$ Measured at the position of the \#3 container, before descending, circling, kinking, ascending, or growing straight into \#15 substrate.

" See Table 1 for descriptions.

${ }^{w}$ Means in a column with a different letter are statistically different at $P<0.05 ; \mathrm{n}=10$, averaged across root pruning treatment due to insignificant interaction $(P>0.20)$

Table 7. Effect of root pruning \#3 and \#15 root balls when shifting to the larger container size on root attributes of 'Florida Flame' red maple in \#45 containers.

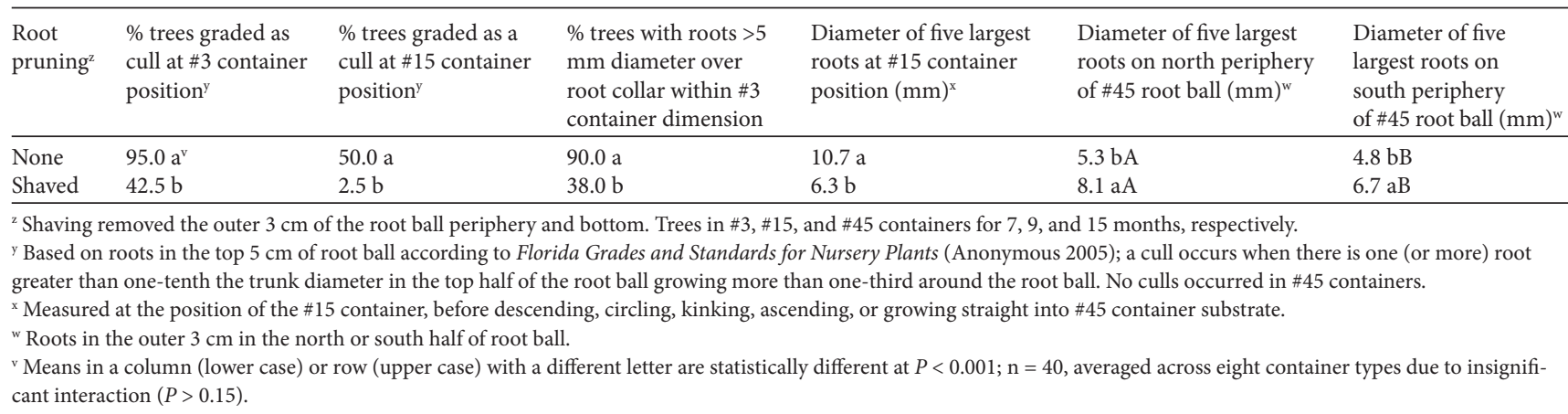


Table 8. Effects of container type on percent trunk circled with roots $>3 \mathrm{~mm}$ diameter at three positions in \#45 containers.

\begin{tabular}{|c|c|c|c|c|}
\hline Container type & Root pruning & $\begin{array}{l}\% \text { trunk circled at } \\
\# 3 \text { container } \\
\text { position }(\%)\end{array}$ & $\begin{array}{l}\% \text { trunk circled at } \\
\# 15 \text { container } \\
\text { position }(\%)\end{array}$ & $\begin{array}{l}\% \text { trunk circled at } \\
\# 45 \text { container } \\
\text { position }(\%)\end{array}$ \\
\hline \multirow[t]{2}{*}{$\mathrm{AP}^{\mathrm{y}}$} & Shaved & $41 \mathrm{f}^{\mathrm{x}}$ & $17 \mathrm{f}$ & $18 \mathrm{~b}$ \\
\hline & None & $82 \mathrm{bc}$ & $39 \mathrm{de}$ & $16 \mathrm{bc}$ \\
\hline \multirow[t]{2}{*}{ CR } & Shaved & $64 \mathrm{de}$ & $7 \mathrm{f}$ & $5 \mathrm{ghi}$ \\
\hline & None & $90 \mathrm{ab}$ & $51 \mathrm{bc}$ & 8 efg \\
\hline \multirow[t]{2}{*}{ FN } & Shaved & $23 \mathrm{~g}$ & $7 \mathrm{~g}$ & $11 \mathrm{de}$ \\
\hline & None & $75 \mathrm{c}$ & $56 \mathrm{ab}$ & $4 \mathrm{hi}$ \\
\hline \multirow[t]{2}{*}{ JP } & Shaved & $38.6 \mathrm{f}$ & $8 \mathrm{~g}$ & $25 \mathrm{a}$ \\
\hline & None & $63.6 \mathrm{e}$ & 64 a & $13 \mathrm{~cd}$ \\
\hline \multirow[t]{2}{*}{$\mathrm{RB}$} & Shaved & $51 \mathrm{e}$ & $6 \mathrm{~g}$ & $12 \mathrm{~cd}$ \\
\hline & None & $88 \mathrm{ab}$ & $54 \mathrm{bc}$ & $6 \mathrm{fgh}$ \\
\hline \multirow[t]{2}{*}{ RT } & Shaved & $34 \mathrm{f}$ & $1 \mathrm{~h}$ & $5 \mathrm{gh}$ \\
\hline & None & $91 \mathrm{ab}$ & $35 \mathrm{e}$ & 9 def \\
\hline \multirow[t]{2}{*}{ SP } & Shaved & $36 \mathrm{f}$ & $14 \mathrm{f}$ & $12 \mathrm{~cd}$ \\
\hline & None & $74 \mathrm{~cd}$ & $39 \mathrm{de}$ & $3 \mathrm{i}$ \\
\hline \multirow[t]{2}{*}{ SS } & Shaved & $37 \mathrm{f}$ & $5 \mathrm{~g}$ & $12 \mathrm{~cd}$ \\
\hline & None & $96 \mathrm{a}$ & $47 \mathrm{~cd}$ & $19 \mathrm{~b}$ \\
\hline
\end{tabular}

${ }^{2}$ Shaving removed the outer $3 \mathrm{~cm}$ of the \#3 and \#15 root ball periphery and bottom. Trees in \#3, \#15, and \#45 containers for 7, 9, and 15 months, respectively. ${ }^{y}$ See Table 1 for descriptions.

${ }^{x}$ Means in a column with a different letter are statistically different at $P<0.05 ; \mathrm{n}=5$.

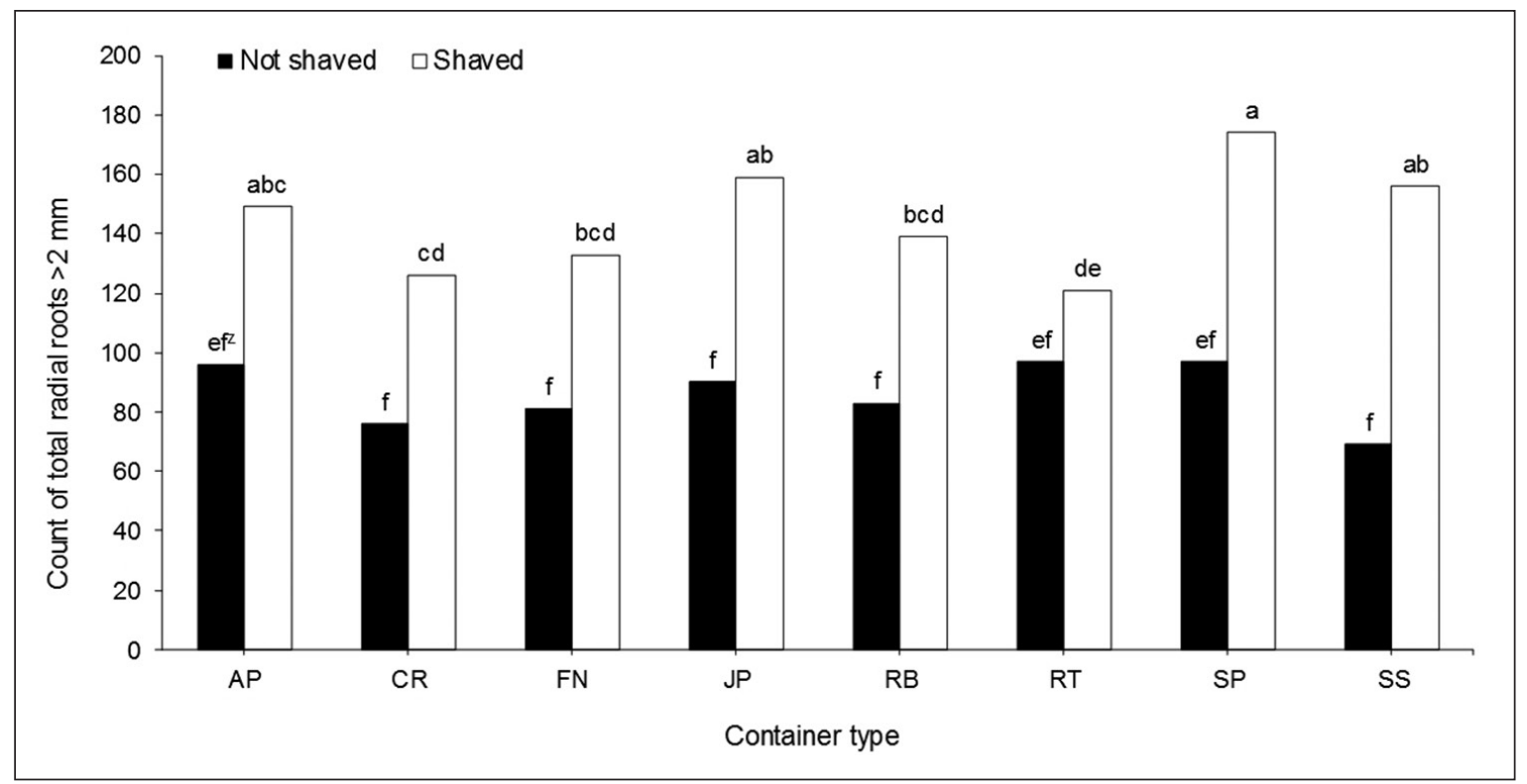

Figure 3. Number of radial roots (roots $>2 \mathrm{~mm}$ diameter growing straight, with less than a 45 degree turn, from trunk reaching \#45 container wall) measured between \#15 and \#45 container wall positions on trees where root balls were shaved or not when shifted into eight \#45 container types (shaving removed the outer $3 \mathrm{~cm}$ of the root ball periphery and bottom). ${ }^{2}$ Bars with a different letter are statistically different at $P<0.05 ; n=5$. See Table 1 for descriptions of container types. 

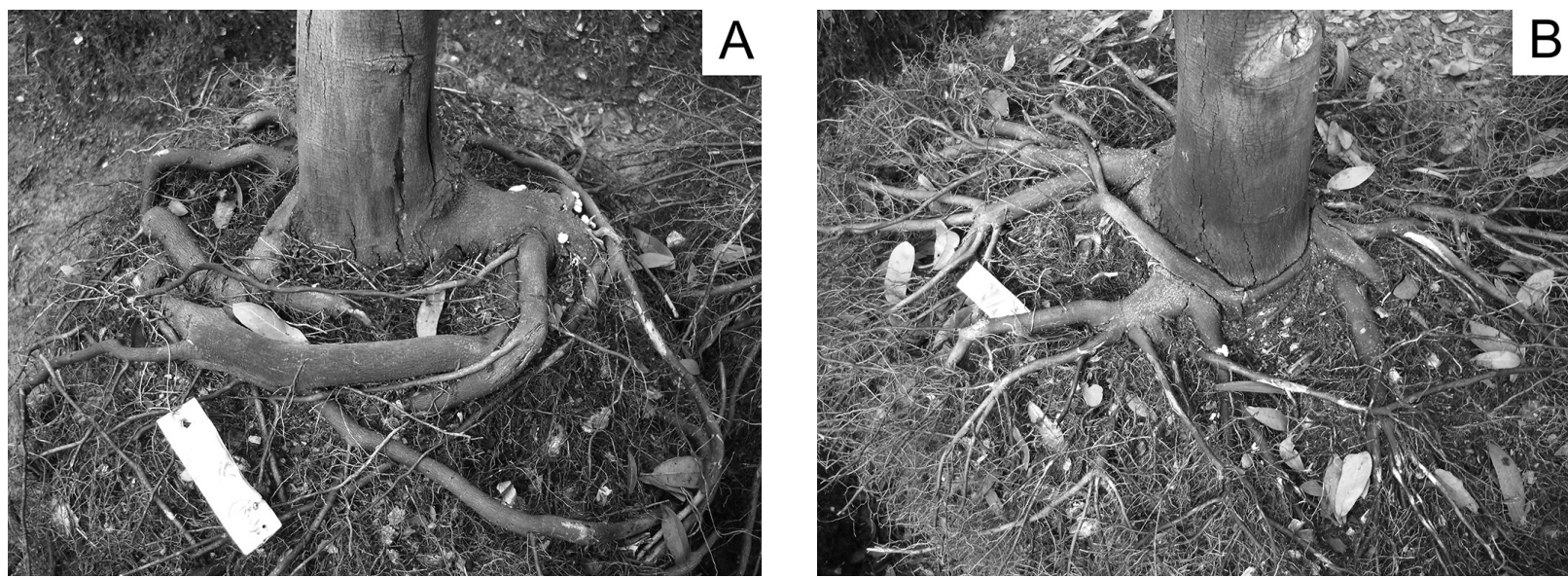

Figure 4. A) Root system from \#45 container not root pruned when shifting showing the prominent imprint from the \#3 container (largest roots circling and descending center and top left) and a smaller imprint from the \#15 container (circling roots bottom right). B) Root system from \#45 container shaved when \#3 and \#15 were shifted to the larger container showing no \#3 or \#15 container imprint; there is a prominent imprint from the liner showing at least half the trunk circled with roots growing tight against the trunk. Liner root balls were not shaved when shifted into \#3 containers. Note: Photographs were taken several months after trees were washed, which explains the cracked and dried appearance of trunk and root bark.

\section{DISCUSSION}

Differences in trunk diameter and tree height growth among container types were small, measured over the course of the three-year study; this was typical of red maple and other taxa in previous studies (Marshall and Gilman 1998, in Florida, U.S.; Owen and Stoven 2008, in Oregon, U.S.; Neal 2009, in New Hampshire, U.S.; Amoroso et al. 2010, in Italy; Stoven O'Conner et al. 2013, in Colorado, U.S.). It appears fair to conclude, based on these studies, that trees grow about the same trunk diameter and height in most container types given appropriate water and nutrient management for the taxa and region, even with a $40 \%$ difference in substrate volume among types (Table 1). Although results could have been different under a different irrigation regime, the cited studies were performed under varying cultural regimes in different climates.

When roots on this same set of trees as the current study were washed and measured from \#3 containers, all container types showed less circling root length (by about one-third) compared to SS; however, circling root length still represented about half of the total root length (roots $>2 \mathrm{~mm}$ diameter) growing on the root ball periphery, with the remaining growing in other directions (Gilman et al. 2010a). Similarly, trees in all \#15 container types not shaved (except RT) had a smaller percentage of trunk circled with roots at the \#3 position than those in SS (Figure 1 ), indicating roots remained in the deflected position and grew larger, thus forming an imprint on the root system. In contrast, only trees in half the \#45 containers (AP, FN, JP, and SP) had a smaller percentage of trunk circled than SS at the \#3 position. It appears that roots smaller than the threshold measured ( $3 \mathrm{~mm}$ diameter) continued to grow in diameter in the circled fashion at the \#3 position as trees were shifted to larger containers, thus resulting in an increase in percentage of trunk circled with time for most container types (Table 8; Figure 4).

It was difficult to isolate one container type that consistently generated roots in all three sizes tested [\#3 (Gilman et al. 2010a), \#15, and \#45] that would be considered the most desirable, although there were trends. Finished trees in \#15 FN and JP were always in the group of containers that had all of the following attributes: the least percentage of trees with roots $>5 \mathrm{~mm}$ diameter growing over the root collar, the smallest diameter roots at the \#3 position, and a relatively small number of ascending roots at the \#3 position (Table 3 ). Trees in JP and SP \#15 containers had more radial roots growing away from the trunk than all other containers not shaved (Figure 2); abundant radial roots have been associated with good anchorage (Ortega et al. 2006). Less deflection may have allowed roots to grow freely 
outward in their natural, shallow position (Lyford and Wilson 1964) into the substrate of the larger container, thus reaching the container wall sooner as shown for Swietenia mahogani (Gilman and Paz 2014). Roots contacting walls sooner should grow to a larger size than those striking the wall later. It is not clear why the container with the smallest volume (JP) was among those with the least amount of root defects, other than roots appeared trapped by the fabric walls instead of deflected. This suggests that container wall attributes may impact root system architecture more so than container volume. There were no correlations between container volume and any measured root attribute. Whereas large roots on the periphery have been thought of as a negative (pers. comm. with horticulturists and arborists), a root system resembling the natural root system may be more likely to develop under this condition, provided these roots are removed by shaving the root ball when shifting to larger containers or planting into the landscape. Presence of only small diameter roots at the periphery of the container to be planted has been associated with more deflection-and therefore a larger imprint of woody roots on the interior of the root ball, resulting from the previous container-and less anchorage after planting (Gilman and Weise 2012; Gilman and Harchick 2014).

FN was the only container type to produce larger diameter roots than SS containers on both the north and south sides of the \#45 root ball periphery (Table 6). This probably occurred because many roots had grown through the fabric of both the \#3 and \#15 container walls and therefore had to be cut for the trees to be removed from all replicates, resulting in a mild form of root-ball shaving. None of the other containers required this treatment.

Absent root pruning, no \#45 container type generated a root system much different in number of radial roots than any other (Figure 3 ). Of the non-shaved containers, JP had the least percentage of trunk circled with roots at the \#3 position, but was in the group of containers with the largest percent circled in \#15 containers (Table 8 ). Trees in AP, RT, and SP \#45 containers stood out because they had the least percentage of trunk circled with roots at the \#15 position (Table 8). Arnold and McDonald (2009) also showed that SP dramatically reduced (by a factor of five) the amount of rose (Rosa spp.) roots at the root ball periphery, compared to SS containers. Marler and Willis (1996) said (no data were presented) that there were fewer circling roots on trees in RB than SS for two tropical species. Moore (2001) found that many Australian tree taxa grown in $20 \mathrm{~cm}$ diameter AP had far fewer circling roots than SS containers eight months after shifting to large containers. Owen and Stoven (2008) noted circling roots in all container types tested, including some in the current study. Red maple in AP for 14 months (Gilman et al. 2010b) and in other container types for 15 months (Marshall and Gilman 1998) eventually developed circling and descending roots, even prior to trees growing larger than standard (Anonymous 2014) size. Roots of younger trees (\#15 containers) grew primarily down at the position of the \#3 container; whereas roots of older trees primarily circled in \#45 containers at the position of the \#15.

Root pruning (shaving) had no impact on trunk growth measured in \#3, \#15, or \#45 containers during the study, although trees may have become stunted from root pruning had irrigation been applied differently. No trees showed symptoms of stress, such as defoliation or tip dieback, and no trees died. Other researchers also reported that the shoots and trunk of trees grew similarly after cutting (by slicing the root ball top-to-bottom) and teasing roots away from the periphery of container root balls (Malieke and Hummel 1990; Arnold and Young 1991). Direct comparisons are difficult to make among the studies, but shaving the root ball likely removed more of the root system than slicing and teasing because shaving severs every root that reaches the periphery of the root ball. This demonstrates, as others have shown (Gilman et al. 2009; Gilman et al. 2010b), that root architecture can be improved by root-ball shaving container-grown shade trees receiving regular irrigation in the nursery without slowing their growth.

Shaving the outer portion of the \#3 root ball when shifting to \#15 appears to result in a substantial decrease in attributes associated with poor root systems (e.g., percentage of trunk circled with roots, Figure 1; percentage of trees graded as culls in \#15 containers, and percentage of the five largest roots circling at the \#3 position, Table 4). The reduction, by about half, in diameter of roots measured at the $\# 3$ position as 
a result of shaving (Table 4) shows the dramatic change in diameter of roots measured a few centimeters from the trunk. Instead of a few roots growing to a large diameter and deflecting in a circling, descending, or ascending manner at the \#3 position, shaving nearly eliminated deflection (Figure 1; Figure 4). The increase in diameter of roots growing on the periphery of the finished \#15 container (Table 4) showed that shaving increased the size of roots reaching the edge of the larger container. Although not directly measured, shaving appeared to shift the root mass farther from the trunk, as in mahogany (Gilman and Harchick 2014). Root deflection at the periphery was nearly eliminated by shaving the \#15 when shifting into \#45 containers (Figure 3).

The impact on anchorage by changing the root system architecture from a few large deflected roots to a larger number of non-deflected, smaller, radially-oriented roots (in seven of eight \#15 containers tested, Figure 2) has not been extensively tested. Other researchers showed that young (fourto seven-year-old) Quercus virginiana Mill. trees with fewer deflected roots and more straight roots were either slightly more stable or equal in stability (depending on measurement date) to trees with many deflected roots inside the root ball (Gilman and Weise 2012). Moreover, reducing root deflections on top of the root ball by root remediation when planting into the landscape reduced occurrence of circling roots and roots growing over the root collar in Acer and Ulmus five years after planting (Gilman et al. 2015a). Although not shown empirically, this may reduce negative impacts on health by reducing the likelihood of stem-girdling root formation. The one container type (JP) may not have responded to shaving because the number of radial roots, even without shaving, was greater than all but one other type (SP, Figure 2). This desirable root attribute in the container with the smallest volume provides further evidence that the container wall configuration influenced root deflection more so than container volume.

Root pruning by shaving the \#3 and \#15 root ball peripheries, as trees were shifted, substantially reduced attributes associated with poor root systems in finished trees in all eight types of \#45 containers (Table 7). This included a dramatic improvement in root system quality by reducing the percentage of trees considered culls from 95\% to $42 \%$ at the $\# 3$, and from $50 \%$ to $2.5 \%$ at the $\# 15$ positions. Moreover, there was a substantial reduction in percent trunk circumference circled by roots at the \#3 and \#15 positions from root pruning (Table 8 ), and a reduced percentage of trees with roots growing over the root collar (Table 7). Root-ball shaving also increased the diameter of the five largest roots at the periphery of the \#45 on the north and south sides of the ball, while decreasing the diameter of the five largest roots at the \#15 position (Table 7). Like trees finished in \#15 containers, this represented a shift in woody root mass away from the trunk. Shaving increased the number (except for RT, Figure 3) of radial roots in finished \#45 containers compared to not shaving, similar to what occurred in \#15 containers when \#3 containers were shaved (Table 4). With more roots growing radially instead of downward or around, forming a cage or imprint of deflected roots, the likelihood of forming a natural root system (Lyford and Wilson 1964; Danjon et al. 2005), with some deep and some shallow roots more or less straight, may improve long-term root system quality and anchorage. The radially oriented root system at the \#3 and \#15 positions allowed more roots to reach the \#45 container side wall (Figure 3), resulting in an increase in percent trunk circumference circled with roots at the \# 45 periphery for four of the eight container types, compared to not shaving (Table 8). However, these can be removed by shaving the root ball periphery when planting into the landscape (Gilman and Wiese 2012). However, it should be noted that shaving the periphery will not correct defects present on the root ball interior, which were severe unless trees were shaved during previous shifts. Landscape contractors should check the interior of the root ball and correct these defects at planting because this taxon appears very prone to root defects. The long-term (more than about seven years) impact on health and anchorage of the root architecture imposed on trees during field and container nursery practices has not been evaluated on any taxa.

Fewer and smaller roots grew on the south side of all \#15 and \#45 containers (Table 5), as Gilman et al. (2010a) observed (not measured) on the same trees as the current study finished in \#3 containers and measured in other studies 
(Martin and Ingram 1988; Ruter 1993). However, there appeared (not measured) to be many live white roots 1 to $2 \mathrm{~mm}$ diameter on the south side positioned about $3 \mathrm{~cm}$ behind the container wall; this could result in more roots growing into landscape soil from the south side once planted into landscape soil. High substrate temperatures are known to cause root death, especially on the sunnier, hotter container side (i.e., south and west side, in Northern Hemisphere, Ruter and Ingram 1992; Owen and Stoven 2008). Results may have been different if containers were turned in random directions as they were shifted to larger containers and not maintained in the same cardinal direction as was done throughout the current study. It is not clear if the root asymmetry generated by the current study's conditions is a desirable or undesirable occurrence regarding anchorage. Also unclear is the potential different response had this study been performed on trees grafted or budded onto seedling root stock.

\section{CONCLUSIONS}

Shaving the root ball periphery when shifting container-grown red maple to the next, larger size impacted root system architecture more so than the eight nursery container types tested. Shaving forced more woody roots to the edge of the \#45 container in a more natural position instead of maintaining a deformed root structure inside the \#3 and \#15 container dimensions. Put another way, shaving nearly eliminated the "imprint" on the root system, caused by growing in a smaller container, without affecting growth in the nursery. However, shaving only reduced defects present at the edge of the pruned root ball, not those on the interior. No one container stood out as producing superior root architecture. Tree orientation in the nursery impacted root architecture resulting in more roots on the cooler northern side of the root ball. The impact of this container-induced asymmetry on health and anchorage remains untested.

\footnotetext{
Acknowledgments. This project was supported by The Cool Ring Company, Lakeland, Florida, U.S.; Fanntum Products, Inc., Statesville, North Carolina, U.S.; Florida Nursery Growers and Landscape Association, Orlando, Florida, U.S.; Horticultural Research Institute, Washington D.C., U.S.; Legacy Nursery Products, LLC, Palm City, Florida, U.S.; Root Control, Inc., Oklahoma City, Oklahoma, U.S.; and Nursery Supplies, Inc., Chambersburg, Pennsylvania, U.S.
}

\section{LITERATURE CITED}

Amoroso, G., P. Frangi, R. Piatti, F. Ferrini, A. Fini, and M. Faoro. 2010. Effect of container design on plant growth and root deformation of littleleaf linden and field elm. HortScience 45:1829-1829.

Anonymous. 2014. American Standard for Nursery Stock. American Nursery Association, Washington D.C., U.S.

Anonymous. 2015. Florida Grades and Standards for Nursery Plants. Florida Department of Agriculture and Consumer Services, Division of Plant Industry, Gainesville, Florida, U.S.

Arnold, M.A., and E. Young. 1991. $\mathrm{CuCO}_{3}$-painted containers and root pruning affect apple and green ash root growth and cytokinin levels. HortScience 26:242-244.

Arnold, M.A., and G.V. McDonald. 2009. Groundcovers, organic, and inorganic mulches, and masonry surfaces differentially affect establishment and root zone characteristics of urban trees. Arboriculture \& Urban Forestry 35:232-240.

Blanusa, T., E. Papadogiannakis, R. Tanner, and R.W.F. Cameron. 2007. Root pruning as a means to encourage root growth in two ornamental shrubs, Buddleja davidii 'Summer Beauty' and Cistus 'Snow Fire'. Journal Horticultural Sciences and Biotechnology 82:521-528.

Danjon, F., T. Fourcaud, and D. Bert. 2005. Root architecture and wind-firmness of mature Pinus piaster. New Phytologist 168:387-400.

Fare, D. 2005. Should potting depth be a concern for container trees? pp. 25-28. In: Proceedings of Trees and Planting: Getting the Roots Right Conference. November 10. The Morton Arboretum, Lisle, Illinois, U.S.

Gilman, E.F., and S. Lilly. 2008. Best Management Practices: Tree Pruning, second edition. International Society of Arboriculture, Champaign, Illinois, U.S.

Gilman, E.F., and C. Harchick. 2008. Planting depth in containers affects root form and tree quality. Journal of Environmental Horticulture 26:129-134.

Gilman, E.F., and C. Harchick. 2014. Root system morphology influences lateral stability of Swietenia mahagoni Arboriculture \& Urban Forestry 40:27-35.

Gilman, E.F., C. Harchick, and M. Paz. 2010a. Effect of container type on root form and growth of red maple. Journal of Environmental Horticulture 28:1-7.

Gilman, E.F., C. Harchick, and C. Weise. 2009. Root pruning effects tree quality in container-grown oaks. Journal of Environmental Horticulture 27:7-11.

Gilman, E.F., J. Miesbauer, C. Harchick, and R.C. Beeson. 2013. Impact of tree size at planting, mulch and irrigation on Acer rubrum L. growth and anchorage. Arboriculture \& Urban Forestry 39:173-181.

Gilman, E.F., and M. Paz. 2014. Root system morphology influenced by container design, retention time, and root pruning. Arboriculture \& Urban Forestry 40:16-26.

Gilman, E.F., M. Paz, and C. Harchick. 2010b. Root ball shaving improves root systems on seven tree species in containers. Journal of Environmental Horticulture 28:13-18.

Gilman, E.F., M. Paz, and C. Harchick. 2015a. Nursery planting depth, mulch application, and root pruning at landscape planting affect tree health and anchorage. Arboriculture \& Urban Forestry 41:75-87. 
Gilman, E.F., M. Paz, and C. Harchick. 2015b. Effect of container type and root pruning on growth and anchorage after planting Acer rubrum L. into landscape soil. Arboriculture \& Urban Forestry (in press).

Gilman, E.F., and C. Wiese. 2012. Root pruning at planting and planting depth in the nursery impact root system morphology and anchorage. Arboriculture \& Urban Forestry 38:229-236.

Halter, M.R., C.P. Chanway, and G.J. Harper. 1993. Growth reduction and root deformation of containerized lodgepole pine saplings 11 years after planting. Forest Ecological Management 56:131-146.

Harris, R.W., W.B. Davis, N.W. Stice, and D. Long. 1971. Influence of transplanting time in nursery production. Journal American Society Horticulture Science 96:109-110.

Harris, J.R., and E.F. Gilman. 1991. Production system affects growth and root regeneration of Leyland cypress, laurel oak, and slash pine. Journal of Arboriculture 17:64-69.

Krasowski, M.J. 2003. Root system modifications by nursery culture effect on post-planting growth and development of coniferous seedlings. Forestry Chronicle 79:882-891.

Lyford, W.H., and B.F. Wilson. 1964. Development of the root system of Acer rubrum L. Harvard Forest Paper No. 10.

Malieke, R., and R.L. Hummel. 1990. Planting landscape plants. Washington State University Cooperative Extension Service, Puyallup, Washington. EB 1505.

Marler, T.E., and D. Willis. 1996. Chemical or air-root pruning containers improve carambola, longam, and mango seedling root morphology and initial root growth after planting. Journal of Environmental Horticulture 14:81-87.

Marshall, M.D., and E.F. Gilman. 1998. Effects of nursery container type on root growth and landscape establishment of Acer rubrum L. Journal of Environmental Horticulture 15:55-59.

Martin, C.A., and D.L. Ingram. 1988. Temperature dynamics in black poly containers. Proceedings Southern Nurseryman Association Research Conference 33:71-74.

Moore, D. 2001. Nursery practices and the effectiveness of different containers on root development. Treenet Proceedings of the 2nd National Street Tree Symposium: Sept 6-7. ISBN 0-9775084-1-2.

Neal, C. 2009. Production systems for small trees and shrubs in New Hampshire. In: G.W. Watson, B. Scharenbroch, L. Costello, and E.F. Gilman (Eds.). The Landscape Below Ground III, Morton Arboretum, October 2008. International Society of Arboriculture, Champaign, Illinois, U.S.

Nichols, T.J., and A.A. Alm. 1983. Root development of containerreared, nursery-growth, and naturally regenerated pine seedlings. Canadian Journal Forest Research 13:239-245.
Ortega, U., J. Majada, A. Mena-Petite, J. Sanchez-Zabala, N. RodriguezItturrizar, K. Txarterina, J. Azpitarte, and M. Duñabeitia. 2006. Field performance of Pinus radiata D. Don produced in nursery with different types of containers. New Forests 31:97-112.

Owen, J., and H. Stoven. 2008. Searching for the perfect pot. Digger, March, Oregon Association Nursery. Wilsonville, Oregon, U.S.

Ruter, J.M. 1993. Growth and landscape performance of three landscape plants produced in conventional and pot-in-pot productions systems. Journal of Environmental Horticulture 11:124-127.

Ruter, J.M., and D.L. Ingram. 1992. High root-zone temperatures influence RuBisCO activity and pigment accumulation in leaves of 'Rotundifolia' holly. Journal American Society Horticultural Science 11:154-157.

SAS Institute, Inc. 1992. SAS/STAT users guide, vers. 9.1.3. SAS Institute, Inc., Cary, North Carolina, U.S.

Stoven O'Connor, A., J.E. Klett, and A.J. Koski. 2013. Container type and overwintering treatments affect substrate temperature and growth of Chanticleer ${ }^{\circ}$ pear (Pyrus calleryana 'Glen's Form') in the Nursery. Journal of Environmental Horticulture 31:117-123.

Tate, R.L. 1980. Detection, description, and treatment of girdling roots on urban Norway maple trees. Ph.D. Thesis, University of Michigan.

\section{Edward F. Gilman (corresponding author) \\ University of Florida \\ Environmental Horticulture \\ 1533 Fifield Hall \\ Gainesville, Florida 32611, U.S. \\ egilman@ufl.edu}

Maria Paz

University of Florida

Environmental Horticulture

1533 Fifield Hall

Gainesville, Florida 32611, U.S.

Chris Harchick

University of Florida

Environmental Horticulture

1533 Fifield Hall

Gainesville, Florida 32611, U.S. 
Résumé. Il existe un consensus à l'effet que les racines sont détournées lorsqu'elles rencontrent la paroi solide des contenants de production en pépinière et que chez les arbres vigoureux, cela se produit dans les quelques semaines suivant leur transfert dans des contenants plus grands. Larchitecture racinaire est mal comprise lorsqu'elle est observée dans des pots aux parois de plastique poreux ou faits de matériaux autres que le plastique. L'objectif de cette étude était de mesurer les impacts en fonction du type de contenant, de la taille des racines au moment de la transplantation dans des contenants plus grands et de la direction cardinale de l'architecture racinaire dans des pots de pépinière jusqu'à un volume de 170 litres (soit \# 45). Le diamètre du tronc dans des pots de 170 litres variait de moins de $5 \mathrm{~mm}$ parmi les huit types de contenants, et sans aucun impact suite à la taille des racines. La croissance racinaire était plus importante du côté nord du pot par rapport à son côté sud. Le type de contenant n'avait qu'un impact léger sur le développement racinaire, en revanche, la taille des racines effectuée en périphérie de la motte à chaque transfert de contenant a eu un impact plus important. La taille des racines périphériques lors du transfert de pot a considérablement réduit le pourcentage d'arbres classés comme rejets et a réduit la formation de racines encerclantes par rapport aux racines non taillées. La taille des racines périphériques a déplacé la masse de racines ligneuses détournées de l'intérieur vers l'extérieur de la motte de racines, permettant une taille plus facile des racines périphériques lors de la plantation dans les aménagements.

Zusammenfassung. Es gibt ein allgemeines Verständnis, dass Wurzeln sich drehen und verbiegen, wenn sie die Wand ihres Pflanzcontainers erreichen und dass das bei gesunden Bäumen innerhalb von Wochen der Umpflanzung in größere Container auftritt. Die Wurzelarchitektur von Bäumen, die in Containern aus porösem Plastik und anderen Materialien als Plastik gezogen werden, ist bislang nur unzureichend verstanden. Das Ziel dieser Studie war es, den Einfluss von Pflanzcontainer-Typen, Wurzelrückschnitt bei der Verpflanzung und Himmelsrichtung auf die Wurzelarchitektur in Containergrößen bis \#45 (ca. 170 l) zu messen. Der Stammdurchmesser in \#45 Containern variierte weniger als $5 \mathrm{~mm}$ bei acht verschiedenen Containertypen und wurde auch nicht durch Schnittmaßnahmen beeinflusst. Auf der Nordseite der Container fand mehr Wachstum statt als auf der Südseite. Der Containertyp hatte nur einen kleinen Einfluss auf die Wurzelarchitektur, während ein Rückschnitt der Wurzeln in Form einer „Rasur“ der Außenseite des Ballens bei der Verpflanzung einen sehr großen Einfluss hatte. Eine Rasur während des Umtopfens reduzierte deutlich den Anteil von Bäumen, die als Ausschussware eingestuft werden und unterdrückte die Bildung von Würgewurzeln im Vergleich zu unrasierten Wurzelballen. Die Rasur verlagert die verdrehte, abgelenkte holzige Wurzelmasse vom Inneren des Wurzelballens nach außen und erleichtert damit das Entfernen von peripheren Wurzeln, wenn der Baum in das Freiland verpflanzt wird.

Resumen. Hay un entendimiento general que las raíces se desvían al llegar a las paredes del contenedor, y que en los árboles con buena vitalidad esto ocurre pocas semanas después de cambiar a contenedores más grandes. La arquitectura de las raíces es poco conocida cuando se observa en recipientes con paredes construidas de plástico poroso y de materiales diferentes al plástico. El objetivo de este estudio fue medir los impactos de tipo contenedor, la poda cuando se pasa a un recipiente más grande, y la dirección cardinal en la arquitectura de la raíz en los contenedores de vivero hasta el tamaño \# 45 (aproximadamente $170 \mathrm{~L}$ ). El diámetro del tronco en contenedores \#45 varió menos de $5 \mathrm{~mm}$ entre ocho tipos de contenedores, y no se vio afectado por la poda de raíces. Se produjo más crecimiento de las raíces en la parte norte de los contenedores que en la mitad meridional. El tipo de envase tuvo un pequeño impacto en la arquitectura de las raíces; en contraste, la poda de la raíz por el recortado de la periferia de la bola de la raíz en cada turno tuvo un gran impacto. El recortado al cambiar redujo dramáticamente el porcentaje de árboles removidos y suprimió la formación de raíces enrolladas en comparación con los afeitados. El recortado cambió la masa de raíces leñosas desviada desde el interior de la bola de la raíz hacia el exterior, por lo que resulta fácil quitar raíces periféricas cuando se plante en el paisaje. 